\title{
Erratum: The plague of Athens
}

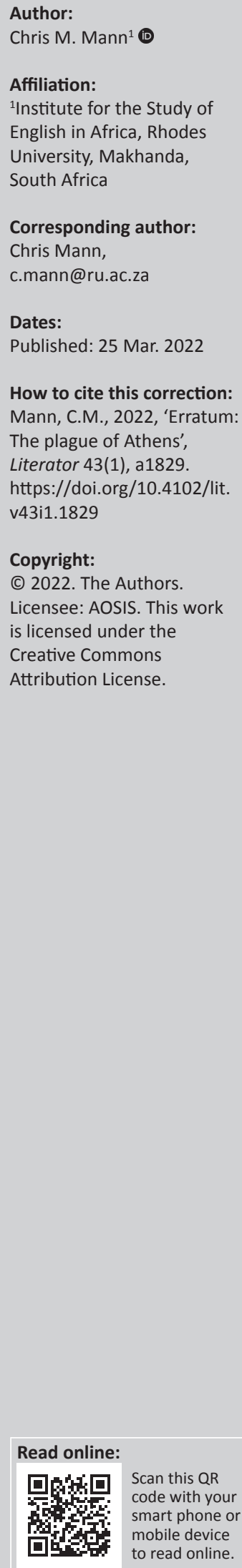

Scan this QR code with your

In the version of this article initially published, Mann, C.M., 2020, 'The plague of Athens', Literator 41(1), a1738. https:/ / doi.org/10.4102/lit.v41i1.1738, the article section was given incorrectly. The correct section should be Litera instead of Original Research.

This correction does not alter the study's findings of significance or overall interpretation of the study's results. The publisher apologises for any inconvenience caused. 


\section{The plague of Athens}

\section{i. The Death of Pericles}

An autumn's equinox, the night air hot and still,

a full moon, high above the rooftops, trees and streets, shapes out a chalk-pale palimpsest of mythic time:

the marble columns of a temple built on rock, a rugged coast, the silence of a calm and silvered sea.

The sad-eyed drinkers in a bar have staggered home, the sage who'd argued Eros off his ivied plinth and broached a woman seer's take, that love's desire torments the soul until it seeks transcendent truth, ponders the glisten of a snail-track on a shadowed wall.

Hush now, this is sleep's pause, the waking hour when thoughts and dreams, as if uplifted by the swells, the pulse and heave of shoreward surging swells, glimmer a midnight city in a cove of rocks, then dark out in the mind-brain's earth-whirled sea.

Look, isn't that grunting nightgown on a bed a temple clerk, totting up wages, grants and fees, the unpaid levies of a league of sea-edged states?

And there, a pearl-pale murmuring still half asleep, isn't that lithe Aspasia crafting a phrase for Pericles?

I wouldn't be a wandering Orpheus of the internet, a fan of rhythmic Homer's word-strung lyre, were I to hide behind a screen of slatted prose the quiet radiance of the moonlight in that room, the unseen resonance that brings to life a dream, a song.
So here's a gleam of leather armour by a bed,

the rippled ivory of a tousled linen sheet,

an inked reed-nib, a black and ochre water jug

around whose clay gymnasium dim figures run,

and on a sill, the moonlit frame and string-set of a harp.

Hush now and let this be, for Pericles has stirred,

the sweat-gleamed torso on the bed, the orator, the energising nexus of a politics, a fleet,

public works, art, a hundred city states has coughed, and sitting up, Aspasia has shrieked, 'Oh no, not more!'

'Water!' he gasps, 'my head's on fire, my body burns!'

He yanks the sheet aside, shudders, twists over then retches a foul-smelling vomit on the tiles,

foul as the rotting kelp and fish strewn on a beach after a storm has roiled and moiled the silt-beds of a shore.

Aspasia kneeling helps him roll back on the bed.

'Don't touch!' he yells, swears, gabbles gibberish, slumps, his face livid, his breath foetid, his eyes blood-red and dulled as if a tide had turned the plankton-seethe of plans inside his soldier-statesman's brain into a bruise-red sludge.

Hush now and let Aspasia's wailing wake the streets and rouse the watchman dozing on the city walls, bring into frame her hands as she wipes clean his face, strokes shut his staring eyes then places on his tongue a coin for his migration to that substrate of space-time, the hum of energy that holograms the underworld.

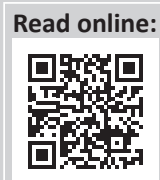

Scan this QR code with your mart phone or mobile device to read online.
Author: Chris M. Mann ${ }^{1}$ (ID

Affiliation: ${ }^{1}$ Institute for the Study of English in Africa, Rhodes University, Makhanda, South Africa

Corresponding author: Chris Mann, c.mann@ru.ac.za

Dates: Received: 31 July 2020 Accepted: 17 Sept. 2020 Published: 09 Nov. 2020

How to cite this article: Mann, C.M., 2020, 'The plague of Athens', Literator 41(1), a1738. https://doi.org/10.4102/lit.v41i1.1738 Copyright: @ 2020. The Authors. Licensee: AOSIS. This work is licensed under the Creative Commons Attribution License. 


\section{ii. The Love Song of Aspasia}

O Pericles, you'd hate to see great Athens now, the streets empty, the best physicians dead, the marketplace a morgue of shuttered stalls.

It's three years on, the clouds beyond the sill scud slowly past the moon like refugees shouldering sacks and trudging to oblivion.

Down at the docks, the quays are desolate, the wine for Syria sours in the heat and weevils waste the sheds of Egypt's grain.

The city's refuse carts stand in their yard, there's sewage, rats and flies in every square and beds and bodies smouldering on pyres.

It's all so hideous, and so terrifying!

Your aunt before she died told visitors the cause is in the very air we breathe,

the foul miasma that the swamps and mist, the stick-and-canvas hovels of the poor, the surly slaves and immigrants exhaled.

'Not so,' that playwright friend of yours replied,

'It's punishment - Athenians have become

so rich and arrogant they've made the gods

the gilded conscripts of their own desires.

Beware the messenger, the Proteus-imp which stalks with death the hubris of mankind.'

He's wrong, he never understood how much recovery from conquest was your mount and people's votes, not luxury, your spur.

I watched you snub the banquets and the bribes and richly fund the warships and the city walls, the athletes, scholars, singers, roads and drains not just that bronze colossus on a hill flaunting a spear higher than the temple in which her ivory double's robed in gold.

Ah Pericles, what of Athena now?

This thing is back, it paused and now it's back more pitiless, more ravenous than before.
What of the stern-eyed, jewelled paragon

of warfare's triumph when there's such hunger, such chaos and despair in Athens now?

Whispering at the door, the scarf-wrapped heads back off when I get up and slowly creep towards the harp still on our sill's dim shrine.

Oh, Pericles, it's three years on tonight, I find it hard to weep, still can't believe I'll never hold you in my arms again or see you on a platform shape in speech the vision of the Athens that you sought or walk with sculptors round the building sites.

How much I wish I were Penelope who knew her mariner would turn for home! But let the harp you loved replace her loom.

You said to me Pythagoras had proved geometry's in the humming of a string and music in the space between the spheres.

So let me lean across the shadowed sill, my taut-strung craft in both my hands, and turn from silent marble on a rock towards the distant glimmer of the sea and throb by throb, fly out into the night a love-song like a bird in search of you.

Oh, Pericles, can't you, don't you hear me? What's life if there's no love, what's love without a wisdom greater than the self? Grim tyrants may restore their grip of iron, rampaging Spartans burn the marketplace, barbarians leave the Parthenon in ruins but there's a permanence in love's desire as strange and lovely as a throbbing string.

Oh Pericles, can't you, don't you hear me? 